Journal of British Studies (ISSN 0021-9371) is published four times a year, in January, April, July, and October, by The University of Chicago Press, 1427 E. 60th Street, Chicago, Illinois 60637, sponsored by the North American Conference on British Studies (NACBS). Beginning with Volume 44, the Journal of British Studies will combine with the journal Albion but will continue to be called the Journal of British Studies and will retain the same ISSN: 0021-9371.

Membership and Subscription Rates: All individual subscriptions to the Journal of British Studies are entered an a calendar-year basis only and are concurrent with membership in the NACBS. All individual and student subscribers are automatically enrolled as NACBS members. Institutional subscriptions have rolling expirations. DUES: 1 year, U.S.A.: members, $\$ 62.00$, students (with copy of validated ID), $\$ 35.00$. Canada: members, $\$ 75.34$; students, $\$ 46.45$. Outside the U.S. and Canada: members, $\$ 76.00$; students, $\$ 49.00$. JBS SUBSCRIPTION ONLY: USA: institutions, $\$ 220.00$. Canada: institutions, $\$ 244.40$. Outside the United States and Canada: institutions, \$234.00. Subscription agent for Japan: Kinokuniya Company, Ltd. Individuals have the option to order directly from the University of Chicago Press. SINGLE COPIES: institutions, $\$ 60.00$, individuals $\$ 20.50$. INQUIRIES AND PAYMENTS for membership and/or subscriptions should be addressed to Journal of British Studies, The University of Chicago Press, P.O. Box 37005, Chicago, Illinois 60637. For subscription information, write; fax, 773/7530811; e-mail, subscriptions@press.uchicago.edu; or phone, 773/753-3347, or 877/705-1878 (tollfree).

Postmaster: Send address changes to Journal of British Studies, The University of Chicago Press, P.O. Box 37005, Chicago, Illinois 60637.

Editorial correspondence: Manuscript submissions to JBS should now be submitted to the incoming editor, Anna Clark (journal.british.studies@umn.edu). Send one hard copy and a disk/CD (either WordPerfect 6.0 or higher or Word for Windows) to Anna Clark, Editor, JBS, 614 Social Sciences Bldg., Dept. of History, University of Minnesota, 267 19th Ave. S, Minneapolis, MN 55455-0406. Authors are encouraged to send submissions to each of the editors as an e-mail attachment in addition to (not in lieu of) the hard copy and disk. All unsolicited manuscripts must be prepared by the author for blind review; that is, all indications of the author's name and institutional affiliation must be removed from the text, header, footer, and notes prior to submission. Articles should conform to the Chicago Manual of Style (15th ed.). The entire text of manuscript, including quotations and endnotes, must be typed double-spaced with generous margins in Times New Roman, 12-point font. Do not justify the right margin. Footnotes should be numbered consecutively and appear at the end of the text. Further guidelines for submissions may be obtained on request from the assistant editor at the above address, or by e-mail directed to journal.british.studies@umn.edu.

Copying beyond Fair Use: The code on the first page of an article in this journal indicates the copyright owner's consent that copies of the article may be made beyond those permitted by Sections 107 or 108 of the U.S. Copyright Law provided that copies are made only for personal or internal use or for the personal or internal use of specific clients and provided that the copier pay the stated per-copy fee through the Copyright Clearance Center (CCC), 222 Rosewood Drive, Danvers, MA 01923. To request permission for other kinds of copying, such as copying for general distribution, for advertising or promotional purposes, for creating new collective works, or for resale, kindly write to Permissions Department, The University of Chicago Press, 1427 E. 60th Street, Chicago, IL 60637.

Advertising space in the Journal of British Studies is available, as is rental of its subscriber list. For information and rates, please contact the advertising sales staff, The University of Chicago Press, Journals Division, 1427 E. 60th Street, Chicago, Ill. 60637. Advertising and list rental are limited to material of scholarly interest to our subscribers.

Periodicals postage paid at Chicago, Illinois, and at additional mailing offices.

(C) 2005 by The North American Conference on British Studies. All rights reserved. 


\section{Empire and Nation}

The American Revolution in the Atlantic World edited by Eliga $H$. Gould and Peter S. Onuf

How did events and ideas from elsewhere in the British empire influence development in the thirteen American colonies? What was the effect of the American Revolution on the wider Atlantic world? Leading historians reconsider the American Revolution as a transnational event, with many sources and momentous implications for Ireland, Africa, the West Indies, Canada, and Britain itself. Anglo-America in the Transatlantic World Jack P. Greene, General Editor

$\$ 49.95$ hardcover

\section{English and Catholic}

The Lords Baltimore in the Seventeenth Century

John D. Krugler

In the sixteenth and seventeenth centuries, to be English and Catholic was to face persecution, financial penalties, and sometimes death. Yet some English Catholics prospered, reconciling their faith and loyalty to their country. Among the most prominent was George Calvert, who embarked on a series of colonial enterprises that eventually led to Maryland. Krugler places the founding and early history of Maryland in the context of pervasive anxieties in England over identity, allegiance, and conscience.

$\$ 46.00$ hardcover

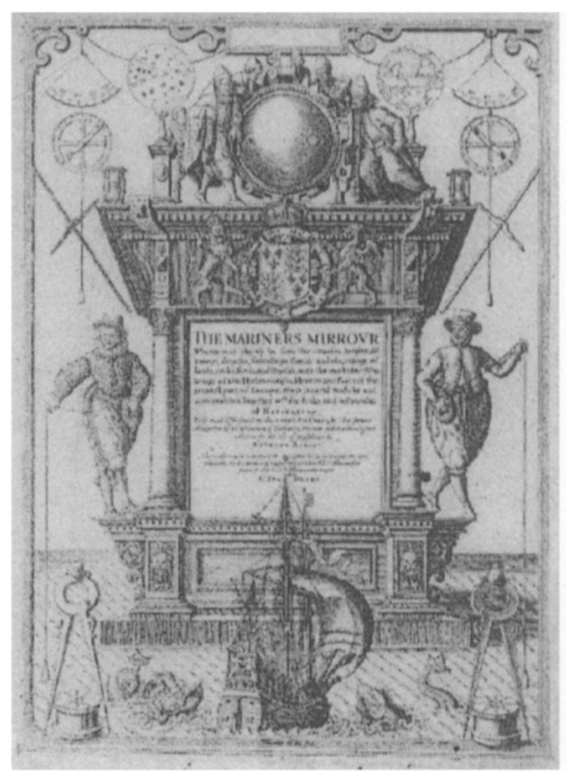

\section{Power, Knowledge, and Expertise in Elizabethan England}

\section{Eric H. Ash}

"An original and compelling study of the invention of a new social role in Elizabethan England: the expert mediator. As detailed by Eric Ash, this development was determined in part by the European rivalry over commercial trade routes and colonial dominion as well as by the increasing centralization of power in England under Henry VIII and Elizabeth. Indeed, this study adds a fascinating dimension not just to accounts of centralization, but also to the story of the rise of modern science." -Pamela Smith, Pomona College

$\$ 45.00$ hordcover

The Johns Hopkins University Press - 1-800-537-5487 • www.press.jhu.edu 


\section{The Last of the Celts}

Marcus Tanner

"In this lively book... independent historian Tanner records the results of his world travels in search of the

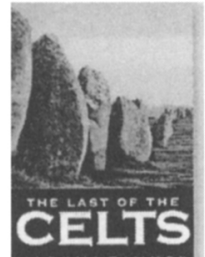
remaining vestiges of Celtic culture.... He provides not only a portrait of modern society in flux in these regions but also a picture of each society's rich history."-Publishers Weekly $\$ 30.00$

\section{The British}

\section{Seaborne}

\section{Empire}

Jeremy Black

Ranging from the period of imperial expansion to the twentieth century,

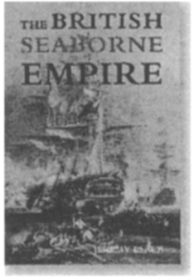

"Black is refreshingly unapologetic about the British Empire and this book is a valuable contribution to the debate about its merits and demerits."

-The Sunday Telegraph

$\$ 40.00$

\section{Napoleon and the British}

\section{Stuart Semmel}

This engaging book reconstructs the role that Napoleon Bonaparte played in the British political, cultural, and religious imagination in the early nineteenth century.

$\$ 40.00$

\section{FitzRoy}

The Remarkable Story of Darwin's Captain and the Invention of the Weather Forecast John Gribbin and Mary Gribbin

"FitzRoy is a fine read and a well-balanced narrative of his life, from his early days as a sailor, through to his time at the helm of the Beagle, and then onwards to his meteorological research."-Dave Musgrove,

\section{Living History}

$\$ 35.00$

\section{Forgotten Lunatics of the Great War}

Peter Barham

In this profoundly moving book, "Barham charts the saga(s) of bureaucratic indifference, callous

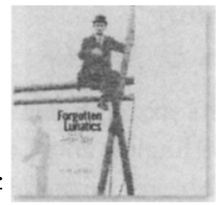
ignorance, and class prejudice with commendable restraint."-Sian Busby,

The Times (London) $\$ 45.00$

\section{Victorians and the Prehistoric}

Tracks to a Lost World

Michael Freeman

This engaging and generously illustrated book explores the Victorian fascination with the prehistoric and the ways that this resounded in British society, art, and literature of the period. $105 \mathrm{~b} / \mathrm{w}+27$ color illus. $\$ 45.00$

\section{IALE University Press ( yalebooks.com}




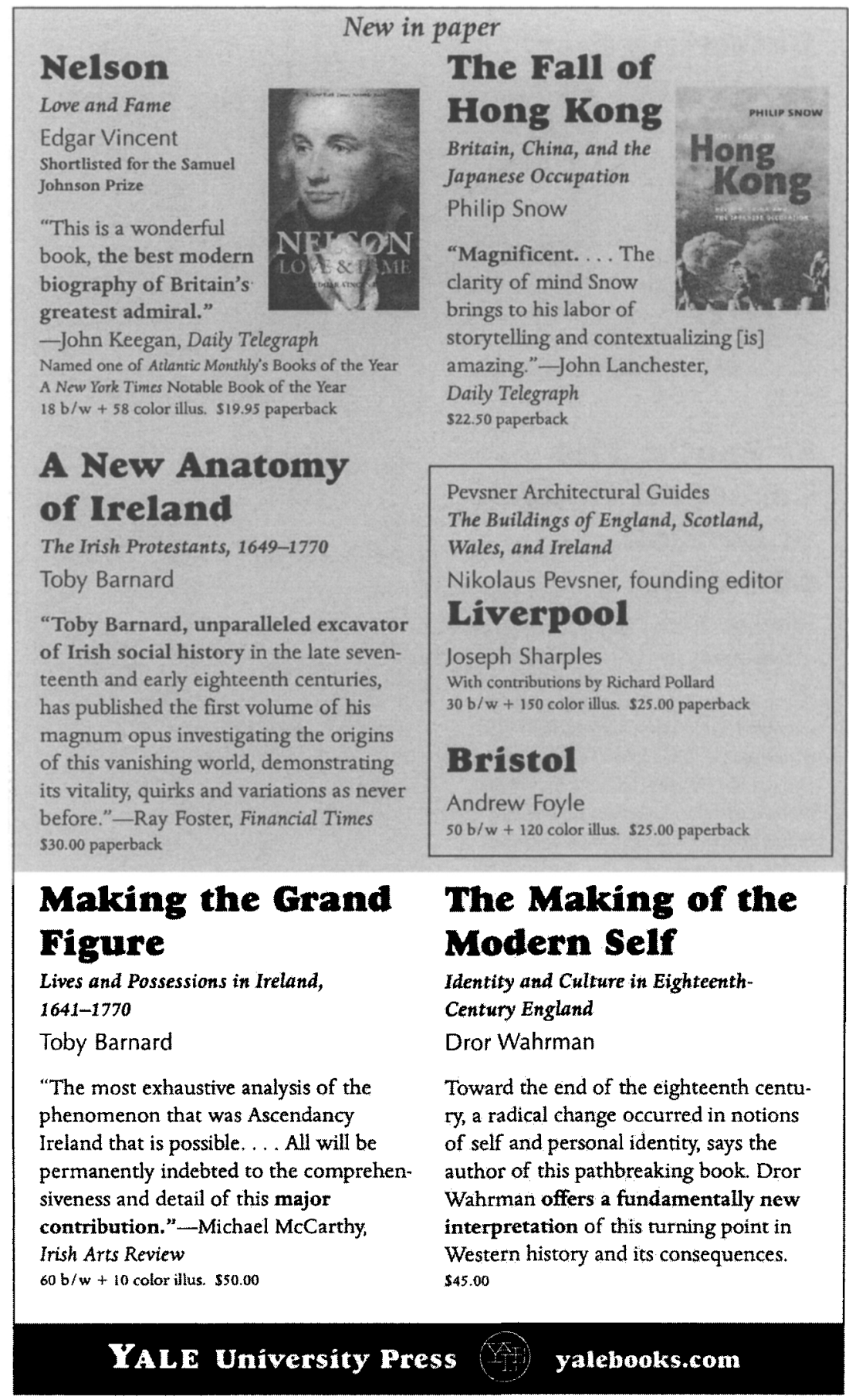




\section{Deceiving the}

\section{Deceivers}

\section{Kim Philby}

Donald Maclean, and Guy Burgess

S. J. Hamrick

This riveting book presents sensational

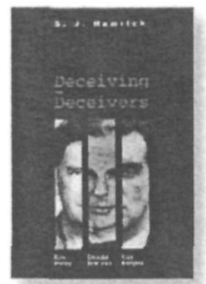

new information on the notorious Cold War espionage case of the three British spies known as the Cambridge Ring. $\$ 29.95$

\section{St Paul's: The}

\section{Cathedral Church}

\section{of London,}

\section{4-2004}

Edited by Derek Keene,

Arthur Burns, and Andrew Saint

"Fascinating. . . . An utterly compelling new book. . . . The illustrations ... are stunning. . . This book is what Wren and his family wanted: a lasting monument worthy of the man and of his emblematic building." - Lisa Jardine, Times (London)

$150 \mathrm{~b} / \mathrm{w}+220$ color illus. $\$ 125.00$

\section{The Kings and} Their Hawks

\section{Falconry in Medieval England}

Robin S. Oggins

"An important contribution to the study of falconry and hawking in medieval England. ... Essential reading for those who wish to understand the households of the kings up to the early fourteenth century."-C. M. Woolgar $15 \mathrm{~b} / w+12$ color illus. $\$ 40.00$
Published for the Paul Mellon Centre for Studies in British Art

\section{William Nicholson}

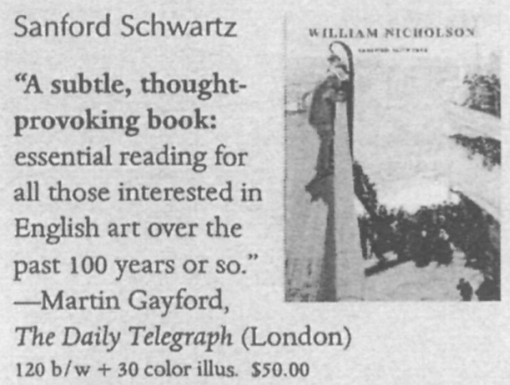

\section{G. F. Watts}

The Last Great

Victorian

Veronica Franklin

Gould

This generously illustrated book is the first in-depth biography of G. F. Watts, the

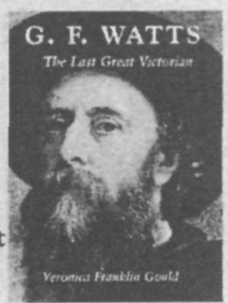
most important portrait painter in nineteenth-century Britain and the father of British Symbolism.

$200 \mathrm{~b} / \mathrm{w}+40$ color illus. $\$ 65.00$

\section{William}

\section{Coldstream}

\section{Bruce Laughton}

"Brings to life the life, times and art of a one-time leading figure in Britain's 20th century art scene. Painter, teacher, Slade lecturer and co-founder of the Euston Road School, Coldstream is masterfully given his due by Bruce Laughton."-Art Times $130 \mathrm{~b} / \mathrm{w}+15$ color illus. $\$ 55.00$

\section{YaLE University Press}


Published for the Paul Mellon Centre for Studies in British Art

\section{Early Georgian} Interiors

\section{John Cornforth}

This gorgeous book surveys the decorative schemes of the country and town houses built in Britain during

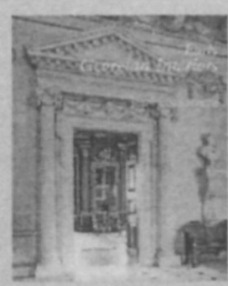
the eighteenth century and considers the effects created by design, furniture, textiles, silver, and artworks. $300 \mathrm{~b} / \mathrm{w}+200$ color illus. $\mathbf{5 8 5 . 0 0}$

\section{Body}

\section{Doubles}

Sculpture in Britain, 1877-1905

David J. Getsy

This lovely book is

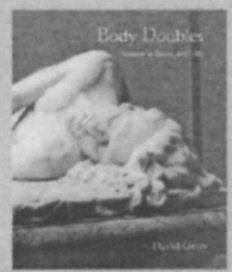

the first to explore the art-theoretical concerns of the late-Victorian sculptors, focusing on their attitudes toward representation of the human body. 150 illus. $\$ 65.00$

\section{Becket's Crown}

Art and Imagination in Gothic England 1170-1300

Paul Binski

This fascinating book offers a new understanding of England's earliest Gothic buildings and art, placing them against a background of the religious and ethical ideals of the individuals and communities that sponsored them. $210 \mathrm{~b} / \mathrm{w}+80$ color illus. $\$ 65.00$

\section{Modern Art,} Britain, and the Great War

Witnessing, Testimony and Remembrance

Susan Malvern

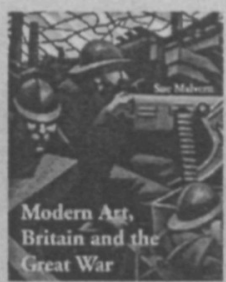

This fascinating book examines how the British state recruited artists to produce official art as part of propaganda during World War I and how their compelling work affected twentieth-century art and British modernism.

$108 \mathrm{~b} / \mathrm{w}+40$ color illus. $\$ 50.00$

\section{Rubens and England}

\section{Fiona Donovan}

This intriguing book is the first to draw a complete picture of the artistic and political connections between the great Flemish artist Peter Paul Rubens and the Stuart court in seventeenth-century England.

$79 \mathrm{~b} / \mathrm{w}+\mathbf{3 0}$ color illus. $\mathbf{5 6 5 . 0 0}$

\section{William Holman Hunt}

A Catalogue Raisonné

Judith Bronkhurst

This gorgeous book presents and discusses the oils, works on paper, and other artistic creations of William Holman Hunt, one of the three major artistic talents of the Pre-Raphaelite brotherhood.

$500 \mathrm{~b} / \mathrm{w}+150$ color illus. $\$ 225.00$

\section{YaLE University Press}




\section{Boydell \& Brewer}

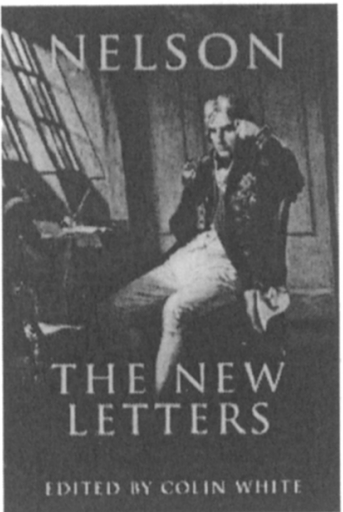

\section{Nelson}

The New Letters

EDITED BY COLIN WHITE

Nelson - The New Letters presents around 450 of the most important letters uncovered during the course of the epic Nelson Letters Project, a five-year search of archives throughout the world. Dating from 1782 and including the earliest extant Nelson letter, this collection shows us both Nelson the officer and Nelson the private man, and, uniquely among the plethora of new Nelson books, it records his life and exploits in his own words.

16 color, 24 b/w illus; 184383130 9, \$39.95/£25.00, April 2005

\section{A Profane Wit}

\section{The Life of John Wilmot, Earl of Rochester}

JAMES WILLIAM JOHNSON

This account of Rochester and his times provides the facts behind his legendary reputation as a rake and his deathbed repentance. However, it also demonstrates that he was a loving if unfaithful husband, a devoted father, a loyal friend, a serious scholar, a social critic, and an aspiring patriot. 24 b/w illus; 443pp, 158046 1700, \$34.95/£25.00, Available Now

\section{The Loss of the Wager}

\section{The Narratives of John Bulkeley and the Hon. John Byron}

JOHN BULKELEY AND JOHN BYRON; INTRODUCTION BY ALAN GURNEY The Loss of the Wager is an eighteenth century melodrama set in a ferociously inhospitable climate on one of the world's most remote and dangerous coastlines.

266pp, $1843830965, \$ 24.95 / £ 14.99$, Available Now

\section{Captain Cook}

\section{Explorations and Reassessments}

EDITED BY GLYNDWR WILLIAMS

Essays reassess Cook's standing as a leading figure in eighteenth-century history, exploration and advancement of science.

$22 \mathrm{~b} / \mathrm{w}$ illus; 288pp, $1843831007, \$ 75.00 / £ 45.00$, Available Now

\section{www.boydellandbrewer.com}


Established by William Rainey Harper in 1884, Journal of Near Eastern Studies provides accurate and authoritative field research, essays, and reviews from all areas of study involved with ancient, medieval, and early modern civilizations of the Near and Middle East. $\boldsymbol{J N E S}$ adds greater depth to scholarly accounts of Near Eastern civilizations by layering multidisciplinary perspectives: archaeology, art, history, literature, linguistics, religion, law, and science, as well as Old Testament and Islamic studies. The result is a broad and lively portrayal of the Near East from internationally renowned scholars.

Edited by Robert D. Biggs

Published quarterly by the University of Chicago Press

\section{Subscribe Today-}

Phone Toll-Free: (877) 705-1878; Fax: (877) 705-1879

Online: www.journals.uchicago.edu/JNES

Email: subscriptions@press.uchicago.edu

\section{The University of Chicago Press • Journals Division • P. O. Box 37005 • Chicago, Illinois 60637}

\section{STATEMENT OF OWNERSHIP, MANAGEMENT AND CIRCULATION \\ (Required by 39 U.S.C. 3685)}

1. Publication title: Joumal of British Studies

2. Publication number: 0021-9371

3. Filing date: September 30, 2004

4. Issue frequency: Four times a year in January, April, July, and October

5. No. of issues published annually: 4

6. Annual subscription price: $\$ 220.00$

7. Complete mailing address of known office of publication: 1427 East 60th Street, Chicago, Cook, IL 60637-2902

8. Complete mailing address of the headquarters or general business offices of the publishers: 1427 East 60th Street, Chicago, Cook, IL $60637-2902$

9. Full names and complete mailing addresses of publisher, editor, and managing editor:

Publisher: The University of Chicago Press, 1427 East 60th Street, Chicago, IL 60637-2902

Editor: James Epstein and Nicholas Rogers, Vanderbilt

University, VU Station B, 351711 Nashville, TN 37235-1711 Managing Editor: None

10. Owner: North American Conference on British Studies Department of History, Reed College, Portland, OR 97202

11. Known bondholders, mortgagees, and other security holders owning or holding 1 percent or more of total amount of bonds, mortgages or other securities: None

12. The purpose, function, and nonprofit status of this organization and the exempt status for Federal income tax purposes have not changed during preceding 12 months

13. Publication name: Journal of British Studies

14. Issue date for circulation data below: July 2004
15. Extent and nature of circulation:

\begin{tabular}{|c|c|}
\hline $\begin{array}{l}\text { A verage } \\
\text { Number } \\
\text { Copies } \\
\text { Each Issue } \\
\text { During } \\
\text { Preceding } \\
12 \text { Months }\end{array}$ & $\begin{array}{l}\text { Actual } \\
\text { Number } \\
\text { Copies of } \\
\text { Single Issu } \\
\text { Published } \\
\text { Nearest to } \\
\text { Filing Date }\end{array}$ \\
\hline 2,056 & 2,059 \\
\hline $\begin{array}{r}1,459 \\
0\end{array}$ & $\begin{array}{r}1,506 \\
0\end{array}$ \\
\hline $\begin{array}{l}0 \\
0\end{array}$ & $\begin{array}{l}0 \\
0\end{array}$ \\
\hline
\end{tabular}

c. Total paid and/or requested

1,459

1,506

d. Free distribution by mail (sarnples, complimentary

and other free copies)

1. Outside-county

2. In-county Subscriptions
3. Other classes mailed through the USPS

e. Free distribution outside the mail

f. Total free distribution (sum of $d \& e$ )

g. Total distribution (sum of $c \& f$ )

h. Copies not distributed:

i. Total (sun of $g$ \&)

j. Percent paid and/or Requested Circulation

$\begin{array}{rr}1 & 1 \\ 0 & 0 \\ 0 & 0 \\ 0 & 0 \\ 1 & 1 \\ 1,460 & 1,507 \\ 596 & 552 \\ 2,056 & 2.059 \\ 100 \% & 100 \%\end{array}$

16. This Statement of Ownership will be printed in the January 2005 issue of this publication.

17. I certify that all information furnished on this forn is true and complete. I understand that anyone who furnishes false or misleading information on this form or who omits material or information requested on the form may be subject to criminal information requested on the form may be subject to criminal
sanctions (including fines and imprisonment) and/or civil sanctions (including civil penalties). 
